Archives de sciences sociales des religions

161 | Janvier-Mars 2013

Messianismes et anthropologie entre France et Italie | Figures et substituts de saints

\title{
Introduction de Messianismes et anthropologie entre France et Italie
}

(2) OpenEdition

Journals

Édition électronique

URL : http://journals.openedition.org/assr/24815

DOI : $10.4000 /$ assr.24815

ISSN : $1777-5825$

Éditeur

Éditions de l'EHESS

Édition imprimée

Date de publication : 1 avril 2013

ISBN : 13-978-2-7132-2394-5

ISSN : 0335-5985

Référence électronique

"Introduction de Messianismes et anthropologie entre France et Italie », Archives de sciences sociales des religions [En ligne], 161 | Janvier-Mars 2013, mis en ligne le 12 juin 2013, consulté le 22 septembre 2020. URL : http://journals.openedition.org/assr/24815; DOI : https://doi.org/10.4000/assr.24815

Ce document a été généré automatiquement le 22 septembre 2020.

(c) Archives de sciences sociales des religions 


\section{Introduction de Messianismes et anthropologie entre France et Italie}

1 Le premier dossier de ce numéro à deux thématiques opère un retour à plusieurs voix et dans diverses perspectives sur l'œuvre de Vittorio Lanternari (1918- 2010), anthropologue italien qui fit connaitre dans les années 1960 les mouvements religieux des peuples opprimés par le colonialisme occidental, messianismes du Tiers Monde dont on se demandait alors s'ils étaient révolutionnaires. Les diverses contributions rassemblées ici reviennent sur ce moment trop oublié où des échanges internationaux très denses et un programme comparatif ambitieux tâchaient de penser les relations du religieux et du politique. L'œuvre de Lanternari y est confrontée à son héritage l'histoire des religions dans ses formes italiennes -, à sa réception - par l'anthropologie française - et à sa mise en débat la plus radicale, par l'ami le plus proche, Ernesto de Martino (1908-1965).

Ce média ne peut être affiché ici. Veuillez vous reporter à l'édition en ligne http:// journals.openedition.org/assr/24815

La rédaction 